\title{
Processing of byproducts to improve nisin production by Lactococcus lactis
}

\author{
Angela Faustino Jozala ${ }^{1,2 \star}$, Daniel P. Silva ${ }^{1}$, António A. Vicente ${ }^{1}$, José A. Teixeira ${ }^{1}$, Adalberto \\ Pessoa Júnior ${ }^{2}$ and Thereza C. V. Penna ${ }^{2}$ \\ ${ }^{1}$ IBB - Institute for Biotechnology and Bioengineering, Centre of Biological Engineering, \\ Universidade do Minho, Braga, Portugal. \\ ${ }^{2}$ Department of Biochemical-Pharmaceutical Technology, School of Pharmaceutical Sciences, \\ University of São Paulo, São Paulo / SP, Brazil.
}

Accepted 29 June, 2011

\begin{abstract}
In the last years, disposal from dairy industries have received a special attention due its polluting power in the environment. For this reason, studies have obtained a positive support to develop different alternatives to recycle milk whey components. One of them is its utilization as culture media, aiming to produce biomolecules with noble applications. Nisin is an extracellular peptide, produced by Lactococcus lactis, this peptide has been applied as a natural additive once it presents broad antibacterial activity. Applications of this bacteriocin include dental care products, pharmaceutical products such as stomach ulcers and colon infection treatment and potential birth control. In batch cultures, $L$. lactis was performed in two different groups of assays. The first group milk whey was prepared in distilled water in four different concentrations: $100 \mathrm{~g} / \mathrm{l}$ (S100); $50 \mathrm{~g} / \mathrm{l}$ (S50); $30 \mathrm{~g} / \mathrm{l}$ (S30); $10 \mathrm{~g} / \mathrm{l}$ (S10). In the second group of assays, two supplements were added in milk whey with concentration 100 $\mathrm{g} / \mathrm{l}$ (S100): (1) $5 \mathrm{~g} / \mathrm{l}$ yeast extract (A1); (2) $5 \mathrm{~g} / \mathrm{l}$ yeast extract and $10 \mathrm{ml}$ (v/v) tomato extract. Nisin activity was assayed through agar diffusion utilizing Lactobacillus sakei. The results show that the utilization of powder milk whey with concentration of $100 \mathrm{~g} / \mathrm{l}$ can be used as a culture medium with supplementation. This media is favorable to develop $L$. lactis cells and nisin production, reaching an activity of about 4 $\log \mathrm{AU}$. Biological processing of milk byproduct can be considered as one of the profitable utilization alternatives, generating high-value bioproducts and stimulates researches for its use.
\end{abstract}

Key words: Nisin, byproducts, Lactococcus lactis, batch culture, powder milk whey.

\section{INTRODUCTION}

Nisin, antimicrobial peptide $(3.4 \mathrm{kDa})$, is produced by Lactococcus lactis ATCC 11454 during its exponential growth phase (Vessoni Penna and Moraes, 2002). Nisin is a bacteriocin commercially used as natural agent for food biopreservation. It has recently been considered safe by the World Health Organization (WHO) and by the Food and Drug Administration (FDA), with the denomination of generally recognized as safe (GRAS) (de Vuyst and Vandamme, 1994; Arauz et al., 2009).

This bacteriocin has large antimicrobial activity spectrum against Gram-positive bacteria and their

\footnotetext{
*Corresponding author. E-mail: angelafj@usp.br. Tel/Fax: +55
} 1130912376. spores, but shows little or no activity against Gramnegative bacteria, yeasts or moulds. However, Gramnegative bacteria can be sensitized to nisin by exposing to chelating agents (EDTA), sublethal heat and freezing (Vessoni Penna et al., 2006).

As a result of its antimicrobial properties, nisin has been accepted as a safe and natural preservative in different areas of food industry and it has also been used as treatment for some health conditions such as stomach and colon ulcers, cosmetic and veterinary products (Delves-Broughton et al., 1996; Liu et al., 2004; Von Sataszewski and Jagus, 2008).

The production of bacteriocins is normally performed in complex growth media: Man Rugosa and Sharpe (MRS), all purpose with Tween (APT), Elliker, brain heart infusion $(\mathrm{BHI})$, tryptone glucose extract (TGE), trypticase soy 
broth (TSB) and trypticase soy broth yeast extract (TSBYE). Although these media promote exuberant growths and have relatively high bacteriocin levels, they have high cost that makes them unsuitable for a largescale production (Guerra et al., 2001). Furthermore, some medium components (for example, large amounts of proteins, which are not totally consumed by the producer strains at fermentation end) may interfere with the subsequent bacteriocin purification (Barefoot and Klaenhammer, 1984).

Although the titers of bacteriocin were lower than those obtained on MRS broth, Guerra et al. (2001) demonstrated the feasibility of the production of nisin and pediocin in an effluent of low cost. The kinetic characterization of both nisin and pediocin production helps to clarify the different effects produced by the nutrient sources (lactose, glycine and potassium phosphate bibasic) used in their work. In addition, the models developed allowed a good construction of the experimental data and identified the key variables in the production of both nisin and pediocin.

Nowadays, whey is a major byproduct of modern cheese and casein industries. On average across the world, volumes of whey are growing at about the same rate as milk volumes (42\% per year; FAO, 2006). This increased quantity of milk is being channeled into the production of larger volumes of cheese, casein/caseinate and other dairy products, resulting in concomitant increases in the whey volume (Smithers, 2008).

Milk whey is a byproduct of dairy industry and contains rich nutrients as lactose, soluble proteins and minerals salts. Unfortunately, whey and its associated nutritional qualities have traditionally been treated as waste and represent an important disposal and pollution issue because of its high biological and biochemical oxygen demand (Liu et al., 2004). Consequently, it is interesting to use this byproduct as fermentation medium for the production of value-added products (Arauz et al., 2009).

The utilization of the milk whey as culture media has been employed in different studies. Guerra et al. (2001) utilized milk whey to produce two different bacteriocins: nisin and pediocin, from Lactococcus lactis and Pediococcus acidilactici, respectively, in batch cultures for $18 \mathrm{~h}$. They observed higher nisin production in diluted whey $(22.9 \mathrm{BU} / \mathrm{ml})$ (mixed with wash waters) (BU: bacteriocin units is the amount of bacteriocin needed to obtain $50 \%$ of growth inhibition measured spectrophotometrically at $700 \mathrm{~nm}$ ) in relation to concentrated whey (liquid remaining after the first cheese pressing) which was $8.3 \mathrm{BU} / \mathrm{ml}$. In another study, Guerra et al. (2007) utilized diluted milk whey with supplements to produced pediocin from $P$. acidilactici.

Flores and Alegre (2001) using supplemented whey during batch fermentation, obtained a maximum nisin activity of $5280 \mathrm{AU} / \mathrm{ml}$ after $9 \mathrm{~h}$ of process ( $\mathrm{pH} 4.9)$. Mondragon-Parada et al. (2006) verified that supplemented filtered whey enhanced the biomass production of lactic acid bacteria. Some researchers applied a mixed culture of L. lactis and Saccharomyces cerevisiae to whey-based medium to stimulate the production of nisin (Liu et al., 2006).

Arauz et al. (2008) utilized three different media with milk whey; (1) without filtration and $\mathrm{pH} 6.8$, adjusted with $\mathrm{NaOH} 1 \mathrm{M}$; (2) without $\mathrm{pH}$ adjustment, and autoclaved at $121^{\circ} \mathrm{C}$ for $30 \mathrm{~min}$; (3) filtered $(1.20$ and $0.22 \mu \mathrm{m}$ membrane filter). Nisin activity was higher in milk whey without filtration with $\mathrm{pH}$ adjusted to 6.8 , and was around 444805.35 AU/ml.

In this research we studied the nisin production in several media through different concentration of powdered milk whey, with or without supplementation.

\section{MATERIALS AND METHODS}

\section{Bacterial strains}

L. lactis ATCC 11454, nisin producer strain and Lactobacillus sakei ATCC 15521, bioindicator of nisin activity, were used in this study. Both microorganisms were maintained at $-60^{\circ} \mathrm{C}$ in MRS broth (Man Rugosa Shepeer-Bacto Lactobacilli MRS broth, DIFCO) with $40 \%$ (v/v) of glycerol (Vessoni Penna et al., 2005; Jozala et al., 2007).

\section{Growth media preparation}

In previous work, the liquid milk whey mixed with wash water was exploited to nisin production (Arauz et al., 2008). In this study, the growth media utilized in the assays for nisin production, was powder milk whey (generously provided by a local dairy plant, Lactogal, Produtos Alimentares S.A., Portugal). The first group of assays milk whey was prepared in distilled water in four different concentrations: $100 \mathrm{~g} / \mathrm{l}$ (S100); $50 \mathrm{~g} / \mathrm{l}$ (S50); $30 \mathrm{~g} / \mathrm{l}$ (S30) and $10 \mathrm{~g} / \mathrm{l}$ (S10). In the second group of assays, two supplements were added to the milk whey with concentration of $100 \mathrm{~g} / \mathrm{l}$ (S100): (1) $5 \mathrm{~g} / \mathrm{l}$ yeast extract (A1); (2) $5 \mathrm{~g} / \mathrm{l}$ yeast extract and $10 \mathrm{ml}(\mathrm{v} / \mathrm{v})$ tomato extract (A2). The growth media $\mathrm{pH}$ was adjusted to 6.8 with $\mathrm{NaOH} 0.1 \mathrm{M}$ and sterilized at $121^{\circ} \mathrm{C}$ for $30 \mathrm{~min}$.

\section{Batch cultures}

Pre-culture was prepared through the cultivation of the $100 \mu \mathrm{l}$ of stock culture $L$. lactis $\left(10^{7} \mathrm{CFU} / \mathrm{ml}\right)$ inoculated into $50 \mathrm{ml}$ of MRS broth in $250 \mathrm{ml}$ flask on rotatory shaker under the follow conditions: $100 \mathrm{rpm}$, at $36 \mathrm{~h}$ and $30^{\circ} \mathrm{C}$. After the $36 \mathrm{~h}, 5 \mathrm{ml}$ aliquot of preculture growth were transferred into $50 \mathrm{ml}$ of milk whey medium (S100, S50, S30, S10, A1 and A2) in $250 \mathrm{ml}$ flask which were incubated for another period of $36 \mathrm{~h}$ in the same conditions described earlier. Each transfer was repeated for 5 times.

After each incubation period, $5 \mathrm{ml}$ was collected aseptically for $\mathrm{pH}$, cell growth and nisin activity analysis. Gram technique was applied to monitor contamination (Arauz at al., 2008; Jozala et al., 2007).

\section{Nisin activity}

Nisin activity was evaluated by agar diffusion method utilizing $L$. sakei as sensitive microorganism. L. sakei was grown in MRS broth and incubated in rotator shaker $\left(100 \mathrm{rpm}, 30^{\circ} \mathrm{C}\right.$ and $\left.24 \mathrm{~h}\right)$. For bioassay, the medium was composed of $0.8 \mathrm{~g}$ of agar (Bacto agar, 


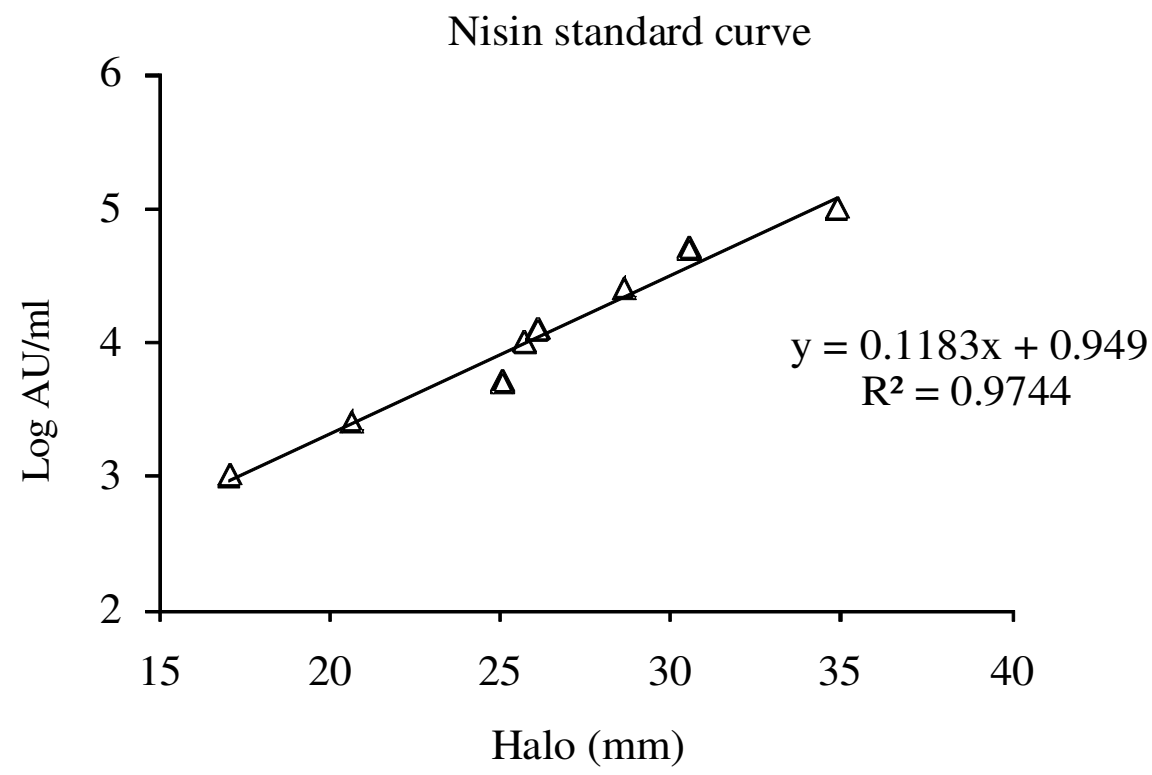

Figure 1. Standard curve of nisin. The relation between arbitrary units $(A U / \mathrm{ml})$ and halo diameter $(\mathrm{H}, \mathrm{mm})$ was determined using concentrations of standard nisin $\left(10^{1}\right.$ to $10^{5} \mathrm{AU} / \mathrm{ml}$ ). Based on calibration curves between $\mathrm{AU} / \mathrm{ml}$ and $\mathrm{IU} / \mathrm{ml}, 1.09 \pm 0.17 \mathrm{AU}$ corresponded to $1.0 \mathrm{IU}$ (40 IU = $1 \mu \mathrm{g}$ of pure nisin).

Difco) for each $100 \mathrm{ml}$ of MRS broth. After autoclaving the agar medium, it was cooled around $40^{\circ} \mathrm{C}$ and inoculated with L. sakei $\left(10^{6} \mathrm{CFU} / \mathrm{ml}\right)$. Each $20 \mathrm{ml}$ was aseptically poured in sterile Petri dishes $(100 \times 15 \mathrm{~mm})$ and after solidified, $3 \mathrm{~mm}$ wells were cut out with a sterile pipe of $5 \mathrm{~mm}$ diameter. Samples from batch culture were centrifuged at $13201 \times \mathrm{g}$ for $10 \mathrm{~min}$ at $10^{\circ} \mathrm{C}$ and the supernatant collected was filtered through a $0.22 \mu \mathrm{m}$ membrane filter; $50 \mu \mathrm{l}$ of supernatant was transferred into the wells of the $L$. sakei inoculated agar. The plates, without inversion were incubated at $30^{\circ} \mathrm{C}$ for $24 \mathrm{~h}$. Afterwards, the diameters of the growth inhibition zones were measured in four directions and the average diameters $( \pm 5 \mathrm{~mm})$ of the halos were related to arbitrary units $(\mathrm{AU} / \mathrm{ml})$. The results were compared with a nisin standard curve.

For the standard curve (Figure 1), a nisin stock solution was prepared by adding $1 \mathrm{~g}$ of commercial nisin (Nisin ${ }^{\circledR}$, Sigma, St. Louis, MO - standard at an activity of $10^{6} \mathrm{AU}$, containing $25000 \mu \mathrm{g}$ of nisin per gram) into $10 \mathrm{ml}$ of $0.02 \mathrm{~mol} / \mathrm{l} \mathrm{HCl}$. The relation between arbitrary units $(\mathrm{AU} / \mathrm{ml})$ and halo diameter $(\mathrm{H}, \mathrm{mm})$ was determined using concentrations of standard nisin $\left(10^{1}\right.$ to $\left.10^{5} \mathrm{AU} / \mathrm{ml}\right)$. Based on calibration curves between $\mathrm{AU} / \mathrm{ml}$ and $\mathrm{IU} \cdot \mathrm{ml}^{-1}, 1.09 \pm 0.17 \mathrm{AU}$ corresponded to $1.0 \mathrm{IU}$ (40 IU = $1 \mu \mathrm{g}$ of pure nisin). The activity of nisin expressed in $\mathrm{AU} / \mathrm{ml}$ was converted to $\mathrm{mg.} \mathrm{I}^{-1}$, through the relation: Nisin $(\mathrm{mg} / \mathrm{l})=(\mathrm{z} \times 0.025)$, where $z=A U / \mathrm{ml}$ and 0.025 is a conversion factor related to $2.5 \%$ of real nisin (Barefoot and Klaenhammer, 1984; Vessoni Penna et al., 2006; Jozala et al., 2007; Pongtharangkul and Demirci, 2004).

\section{RESULTS AND DISCUSSION}

The influence of the milk whey in the behavior of $L$. lactis was analyzed taking $5 \mathrm{ml}$ of the culture of each transfer process, as previously reported in our earlier works (Vessoni Penna et al., 2005, 2006; Jozala et al., 2005, 2007).

The pre culture of $L$. lactis in MRS broth showed the activities of 3.27 and $3.37 \log \mathrm{AU}$, that is equals to 46.53 and $58.17 \mathrm{mg} / \mathrm{l}$, respectively, with a growth of approximately $10^{6} \mathrm{CFU} / \mathrm{ml}$; both used to initiate the culture with milk whey. The growth and nisin formation, in the pre culture, is due to the fact that, MRS broth contained complex nutrients, keeping ideal conditions for the start of the assays in the culture media of milk whey and supplements (Table 1), named as S100, S50, S30, S10, $\mathrm{A} 1$ and $\mathrm{A} 2$.

The medium $\mathrm{S} 100$ showed $L$. lactis growth in all transfers, and nisin activity was detected only in the 2nd and 5th transfer, corresponding to 2.56 and $3.33 \log \mathrm{AU}$, which was equal to 9.12 and $53.93 \mathrm{mg} / \mathrm{l}$, respectively. The same behavior was noted in the medium S50; the nisin activity was detected only in the 1st and 5th transfers, corresponding to 2.59 and $2.65 \log \mathrm{AU}$ which was equal to 9.83 and $11.23 \mathrm{mg} / \mathrm{l}$, respectively. In both assays, $\mathrm{S} 100$ and $\mathrm{S} 50, \mathrm{pH}$ values were around 5.4.

For assays $\mathrm{S} 30$ and $\mathrm{S} 10$, culture medium were more diluted than that of S100 and S50 and some nutrients are necessary to microorganism development gotten in smaller concentration. For this reason, the culture medium proportioned to the $L$. lactis cells was not a favorable environment for the growth.

Although the media S100 was the best conditions for the development of $L$. lactis cells and the nisin release (Table 2), compared with the results giving by the media S10 and S30, it was impossible to detect linearity in the activities. This could be associated with the absence of nutrients in the culture media, as reported in the work of Jozala et al. (2007) who observed that the concentration equilibrium of the nutrients in a medium was essential for 
Table 1. Culture media in different concentrations of milk whey and supplements $(\mathrm{g} / \mathrm{l})$.

\begin{tabular}{lcccccc}
\hline Culture & S10 & S30 & S50 & S100 & A1 & A2 \\
\hline Milk whey & 10 & 30 & 50 & 100 & 100 & 100 \\
Yeast extract & - & - & - & - & 5 & - \\
Tomato extract & - & - & - & - & - & 10 \\
\hline
\end{tabular}

- Not added.

Table 2. Nisin activity and concentration in each transfer of the L. lactis cells in batch culture utilizing different concentrations of milk whey under the conditions of $100 \mathrm{rpm}$ at $30^{\circ} \mathrm{C}$ for $36 \mathrm{~h}$.

\begin{tabular}{|c|c|c|c|c|c|c|c|}
\hline \multirow{7}{*}{$\begin{array}{l}\text { Milk whey }(100 \mathrm{~g} / \mathrm{l})(\mathrm{S} 100) \\
\text { initial } \mathrm{pH}: 6.6\end{array}$} & Transfer & $\mathrm{CFU} / \mathrm{ml}$ & $\mathrm{pH}$ & Halos (mm) & ${ }^{\mathrm{a}} \mathrm{AU} / \mathrm{ml}$ & $\log (A U)$ & ${ }^{b} \mathrm{mg} / \mathrm{l}$ \\
\hline & Pre culture (MRS) & $2.5 \times 10^{6}$ & 4.89 & 19.62 & 1861.02 & 3.27 & 46.53 \\
\hline & 1 & $1.3 \times 10^{4}$ & 5.41 & - & - & - & - \\
\hline & 2 & $8.7 \times 10^{4}$ & 5 & 13.64 & 364.77 & 2.56 & 9.12 \\
\hline & 3 & $1.9 \times 10^{5}$ & 5.58 & - & - & - & - \\
\hline & 4 & $2.13 \times 10^{5}$ & 5.68 & - & - & - & - \\
\hline & 5 & $4.2 \times 10^{5}$ & 5.44 & 20.16 & 2157.39 & 3.33 & 53.93 \\
\hline \multirow{6}{*}{$\begin{array}{l}\text { Milk whey }(50 \mathrm{~g} / \mathrm{l})(\mathrm{S} 50) \\
\text { initial } \mathrm{pH}: 6.6\end{array}$} & Pre culture (MRS) & $2.5 \times 10^{6}$ & 4.89 & 19.62 & 1861.02 & 3.27 & 46.53 \\
\hline & 1 & $1.7 \times 10^{4}$ & 5.45 & 13.91 & 393.15 & 2.59 & 9.83 \\
\hline & 2 & $3.2 \times 10^{4}$ & 5.33 & - & - & - & - \\
\hline & 3 & $1.7 \times 10^{5}$ & 5.76 & - & - & - & - \\
\hline & 4 & $1.8 \times 10^{5}$ & 5.59 & - & - & - & \\
\hline & 5 & $2.2 \times 10^{5}$ & 5.68 & 14.40 & 449.28 & 2.65 & 11.23 \\
\hline \multirow{6}{*}{$\begin{array}{l}\text { Milk whey }(30 \mathrm{~g} / \mathrm{l}) \text { (S30) } \\
\text { initial } \mathrm{pH}: 6.6\end{array}$} & Pre culture (MRS) & $2.5 \times 10^{6}$ & 4.82 & 19.62 & 1861.02 & 3.27 & 46.53 \\
\hline & 1 & - & 4.33 & - & - & - & - \\
\hline & 2 & - & 5.2 & - & - & - & - \\
\hline & 3 & - & 5.26 & - & - & - & - \\
\hline & 4 & - & 5.39 & - & - & - & - \\
\hline & 5 & - & 5.5 & - & - & - & - \\
\hline \multirow{6}{*}{$\begin{array}{l}\text { Milk whey }(10 \mathrm{~g} / \mathrm{l})(\mathrm{S} 10) \\
\text { initial } \mathrm{pH}: 6.6\end{array}$} & Pre culture (MRS) & $2.5 \times 10^{6}$ & 4.82 & 19.62 & 1861.02 & 3.27 & 46.53 \\
\hline & 1 & - & 4.1 & - & - & - & - \\
\hline & 2 & - & 5.33 & - & - & - & - \\
\hline & 3 & - & 5.76 & - & - & - & - \\
\hline & 4 & - & 5.59 & - & - & - & - \\
\hline & 5 & - & 5.68 & - & - & - & - \\
\hline
\end{tabular}

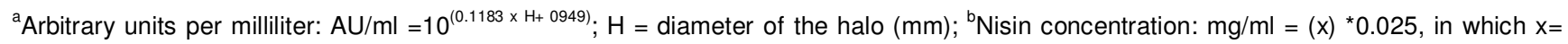
activity $(\mathrm{AU} / \mathrm{ml})$ and is a conversion value related with $2.5 \%$ of pure nisin.

the higher nisin productivity by L. lactis cells.

Besides, the lactic bacteria are fastidious and require culture media with high nutritional value, which increase the growth and the bacteriocin production. Many studies describe the MRS and M17 broth as great culture media used for cellular growth and bacteriocin production by the
L. lactis (Biswas et al., 1991; Toba et al., 1991; Brink et al., 1994; Reid et al., 1998; Cheigh et al., 2002)

Guerra and Pastrana (2002) observed that nutrient sources were not adequate to increase bacteriocin production on diluted whey. Further studies based on the search for other sources (like yeast extract or peptones) 
Table 3. Nisin activity and concentration in each transfer of the L. lactis cells in batch culture utilizing different concentrations of milk whey supplemented under the conditions of $100 \mathrm{rpm}$ at $30^{\circ} \mathrm{C}$ for $36 \mathrm{~h}$.

\begin{tabular}{|c|c|c|c|c|c|c|}
\hline Transfer & CFU/ml & $\mathrm{pH}$ & Halos $(\mathrm{mm})$ & ${ }^{\mathrm{a}} \mathrm{AU} / \mathrm{ml}$ & $\log (A U)$ & ${ }^{b} \mathrm{mg} / \mathrm{l}$ \\
\hline \multicolumn{7}{|c|}{ Milk whey $(100 \mathrm{~g} / \mathrm{l})$ with yeast extract 5 (g/l) (A1) initial pH: 6.3} \\
\hline Pre culture (MRS) & $2.5 \times 10^{6}$ & 4.96 & 20.44 & 2326.78 & 3.37 & 58.17 \\
\hline 1 & $1.7 \times 10^{4}$ & 4.55 & 16.09 & 711.46 & 2.85 & 17.79 \\
\hline 2 & $3.2 \times 10^{4}$ & 5.15 & - & - & - & - \\
\hline 3 & $1.7 \times 10^{5}$ & 5.04 & 16.57 & 810.84 & 2.91 & 20.27 \\
\hline 4 & $1.8 \times 10^{5}$ & 4.96 & 16.59 & 815.27 & 2.91 & 20.38 \\
\hline 5 & $2.2 \times 10^{5}$ & 4.65 & 17.91 & 1167.24 & 3.07 & 29.18 \\
\hline
\end{tabular}

$\begin{array}{ccccccc}\text { Milk whey (100 } \mathbf{g} / \mathbf{l}) \text { with yeast extract } & \mathbf{( 5} \mathbf{~} \mathbf{g} \mathbf{l}) \text { and } \mathbf{1 0} \mathbf{~} \mathbf{l} \text { tomato extract } \mathbf{( v / v ) ( A 2 ) ~ i n i t i a l ~} \mathbf{~ p H : ~} \mathbf{6 . 1} \\ \text { Pre culture (MRS) } & 2.5 \times 10^{6} & 4.96 & 20.44 & 2326.78 & 3.37 & 58.17 \\ 1 & 1.2 \times 10^{3} & 4.53 & 15.04 & 534.49 & 2.73 & 13.36 \\ 2 & 1.5 \times 10^{4} & 5.16 & 17.73 & 1113.67 & 3.05 & 27.84 \\ 3 & 1.6 \times 10^{4} & 4.98 & 16.55 & 806.43 & 2.91 & 20.16 \\ 4 & 1.8 \times 10^{4} & 4.89 & - & - & - & - \\ 5 & 2.0 \times 10^{4} & 4.54 & 17.31 & 993.27 & 3.00 & 24.83\end{array}$

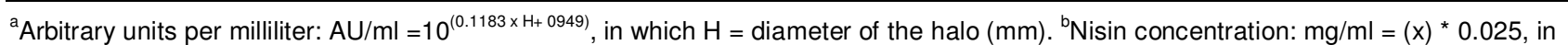
which $\mathrm{x}=$ activity $(\mathrm{AU} / \mathrm{ml})$ and is a conversion value related with $2.5 \%$ of pure nisin.

are needed to optimize the unbuffered whey composition.

In additional, the same authors utilized yeast extract, lactose and glucose for supplements into the milk whey for bacteriocin production. They observed that the use of feeding substrates containing glucose instead of lactose could be an appropriate alternative for increasing fedbatch production of pediocin (Guerra et al., 2007).

Jozala et al. (2007) showed that nutritional components of skimmed milk diluted with $2.27 \mathrm{~g}$ total solids (maximum of nisin $501.93 \mathrm{mg} / \mathrm{l}$ ), influenced the nisin expression by the cells during the cultivation, suggesting that milk whey could increase nisin production and reduced the cost of production of this biomolecule.

According to the research, the maximum nisin values obtained in that study in milk whey not filtered (11120.13 $\mathrm{mg} / \mathrm{l})$ was 22 fold higher than the milk whey diluted. Since the culture media is of low cost, the higher nutritional content of milk and milk whey gave an excellent growth condition for the $L$. lactis and nisin expression.

Observing the results obtained in milk whey, we choose to use nutritional supplements. By the analysis of the bibliography, we tried to put in this study culture media that promote the growth and nisin excretion by the microorganism. Based on the ATCC site: (http://www. Igcstandardsatcc.org/LGCAdvancedCatalogueSearch/Pr oductDescription/tabid/1068/Default.aspx) the ideal culture media for the development of $L$. lactis cells contain yeast extract, tomato juice and milk. Because of this information, two culture media containing, separately, yeast extract and tomato extract utilization was elaborated as base culture media; $\mathbf{S 1 0 0}$ in this study (Table 1).
The supplementations of the media gave a better adaptation for the nisin producing cells. We observed in the transfers, a higher linearity between the results. In the A1 medium containing yeast extract, the nisin activity observed in the 1st transfer was $2.85 \log A U$, corresponding to $17.79 \mathrm{mg} / \mathrm{l}, \mathrm{pH} 4.55$ and cellular growth of approximately $10^{4} \mathrm{log}$ CFU $/ \mathrm{ml}$. Higher activity was observed in the 5th transfer as $3.07 \log \mathrm{AU}$ corresponding to $29.18 \mathrm{mg} / \mathrm{l}, \mathrm{pH} 4.65$ and cellular growth of approximately $10^{5} \mathrm{log} \mathrm{CFU} / \mathrm{ml}$. In the 2 nd transfer, nisin activity was not detected and could be related to the $\mathrm{pH}$ value of 5.15 (Table 3 ).

In the A2 medium, containing the tomato extract, the nisin activity was observed during the first three transfers, giving the values $2.73,3.05$ and $2.91 \log \mathrm{AU}$, respectively for the first, second and third transfers. In the 5th transfer, the nisin activity was $3 \log \mathrm{AU}$, at $\mathrm{pH} 4.54$ with cellular growth of $10^{4} \mathrm{CFU} / \mathrm{ml}$.

The cellular growths were stable during all the process. However, nisin activity was not detected in the 4th transfer which can be attributed to the increase of the $\mathrm{pH}$. This phenomena occurred in the assay with A1 medium; the 2nd transfer did not show nisin activity and the $\mathrm{pH}$ value was similar to the $\mathrm{pH}$ of the 4th transfer of the A2 medium assay, around 5.15 (Table 3 ). Comparing the assay $A 1$ and $A 2$, both media showed the same results.

Nisin production is affected by several cultural factors such as producer strain, nutrient composition of media, $\mathrm{pH}$, temperature, agitation and aeration, and also by other factors, such as substrate and product inhibition, adsorption of nisin onto the producer cells and enzymatic degradation (Chandrapati and O'Sullivan, 1998). 
In this study for all assays, no decrease in nisin titers was observed and the highest nisin activity was detected in $\mathrm{pH}<5$. In $\mathrm{pH}$ values smaller than 6 , at least, $80 \%$ of the nisin expressed by the cells were released in the culture medium. On the other hand, in $\mathrm{pH}$ higher than 6 , most of the nisin could be retained in the cellular membrane or be inside the cells (Chandrapati and O'Sullivan, 1998; Parente and Ricciardi, 1999; Yang et al., 1992).

\section{Conclusion}

Although the work was developed by Arauz et al. (2008), the utilization of milk whey without the supplementation of nutrients was showed to be a great medium for the nisin formation and dispersion by L. lactis. The results showed that the utilization of powder milk whey can be used as a fermentation medium with supplementation. The supplementation was essential for the formation and dispersion of nisin by L. lactis; in this case, the higher nisin concentration is related to nitrogen fonts present in the medium.

The hypotheses for these results could be associated with the kind of treatment that was probably used to obtain the milk whey. Biological processing of byproducts (milk whey) can be considered one profitable alternative, generating high-valued bioproducts. Using this low-cost media on the microbial cultures promotes economical advantages, reducing environment pollution and stimulates researches for the use of this byproduct. Further studies based on different powder milk whey concentration with supplementation should be delineated.

\section{ACKNOWLEDGEMENT}

The authors wish to thank the Brazilian Committees for the Scientific Technology Research (CNPq, FAPESP, CAPES), for financial support and scholarship.

\section{REFERENCES}

Arauz LJ, Jozala AF, Pinheiro GS, Mazzola PG, Pessoa-Júnior A, Vessoni Penna TC (2008). Nisin expression production from Lactococcus lactis in milk whey medium. J. Chem. Technol. Biotechnol. 83: 325-328.

Arauz LJ, Jozala AF, Mazzola PG, Vessoni Penna TC (2009) Nisin Biotechnological Production and Application: a review. Trends in Food Technol. 20: 146-154.

Barefoot SF, Klaenhammer TR (1984). Detection and activity of lactacin $\mathrm{B}$, a bacteriocin produced by Lactobacillus acidophilus. Appl. Environ. Microbiol. 45: 1808-1815.

Biswas SR, Ray P, Johnson MC, Ray B (1991). Influence of Growth Conditions on the Production of a Bacteriocin, Pediocin $\mathrm{AcH}$ by Pediococcus acidilactici. H. Appl. Environ. Microbiol. 57(4): 12651267.

Brink B, Minekus M, Van Der Vossen JM, Leer RJ, Huis Int Veld JH (1994). Antimicrobial activity of lactobacilli: preliminary characterization and optimization of production of acidocin $\mathrm{B}$, a novel bacteriocin produced by Lactobacillus acidophilus M46. J. Appl. Bacteriol. 77: 140-148.
Chandrapati S, Sullivan ODJ (1998). Procedure for quantifiable assessment of nutritional parameters influencing Nisin production by Lactococcus lactis subsp. Lactis. J. Biotechnol. 63(3): 229-233.

Cheigh $\mathrm{Cl}$, Choi HJ, Park H, Kim SB, Kook MC, KimTS, Hwang JK, Pyun YR (2002). Influence of growth conditions on the production of a nisin-like bacteriocin by Lactococcus lactis subsp. lactis A164 isolated from kimchi. J. Biotechnol. 95(3): 225-235.

De Vuyst L, Vandamme EJ (1994). Lactic acid bacteria and bacteriocins: Their practical importance. In Bacteriocins of lactic acid bacteria: Chapman and Hall. 1(12).

Delves-Broughton J, Blackburn P, Evans RJ, Hugenholtz J (1996). Applications of the bacteriocin nisin. Antonie Leeuwenhoek, 69(2): 193-202.

Flores SH, Alegre RM (2001). Nisin production from Lactococcus lactis ATCC 7962 using supplemented whey permeate. Biotechnol. Appl. Biochem. 34(2): 103-107.

Guerra NP, Bernárdez PF, Castro PL (2007). Fed-batch pediocin production on whey using different feeding media. Enzyme Microb. Tech. 41: 397-406.

Guerra NP, Pastrana L (2002). Nisin and pediocin production on mussel-processing waste supplemented with glucose and five nitrogen sources. Lett Appl. Microbiol. 34: 114-118.

Guerra NP, Rua ML, Pastrana L (2001). Nutritional factors affecting the production of two bacteriocins from lactic acid bacteria on whey. Int. J. Food Microbiol. 70: 267-281.

Jozala AF, Andrade MS, Arauz LJ, Pessoa Jr. A, Vessoni Penna TC (2007). Nisin production utilizing skimmed milk aiming to reduce process cost. Appl. Biochem. Biotechnol. 136-140: 515-528.

Jozala AF, Novaes LCL, Cholewa O, Moraes D, Vessoni Penna TC (2005). Increased of Nisin Produced by Lactococcus lactis in Different Media. Afr. J. Biotechnol. 4(3): 262-265.

Liu C, Hu B, Liu Y, Chen S (2006). Stimulation of nisin production from whey by a mixed culture of Lactococcus lactis and Saccharomyces cerevisiae. Appl. Biochem. Biotechnol. 129-132: 751-761.

Liu C, Liu Y, Liao W, Wen Z, Chen S (2004). Simultaneous production of nisin and lactic acid from cheese whey: optimization of fermentation conditions through statistically based experimental designs. Appl. Biochem. Biotechnol. 113-116: 627-638.

Mondragón-Parada ME, Nájera-Martínez M, Juárez-Ramírez $C$, Galíndez-Mayer J, Ruiz-Ordaz N, Cristiani-Urbina E (2006). Lactic acid bacteria production from whey. Appl. Biochem. Biotechnol. 134(3): 223-232.

Parente E, Ricciardi A (1999). Production, recovery and purification of bacteriocins from lactic acid bacteria. Appl. Microbiol. Biotechnol. 52: 628-638.

Pongtharangkul T, Demirci A (2004). Evaluation of agar diffusion bioassay for nisin quantification. Appl. Microbiol. Biotechnol. 65(3): 268-272.

Reid G, McGroarty JA, Angotti R, Cook RL (1998). Lactobacillus inhibitor production against Escherichia coli and coaggregation ability with uropathogens. Can. J. Microbiol. 34(3): 974-978.

Smithers GW (2008) Whey and whey proteins-From 'gutter-to-gold: Rev. Int. Dairy J. 18: 695-704.

Toba T, Samant SK, Toshiota E, Itoh T (1991). Reutericin 6, a new bacteriocin produced by Lactobacillus reuteri LA6. Lett. Appl. Microbiol. 13: 281-286.

Vessoni Penna TC, Jozala AF, Gentille TR, Pessoa Jr. A, Cholewa O (2006). Detection of nisin expression by Lactococcus lactis using two susceptible bacteria to associate the effects of nisin with EDTA. Appl. Biochem. Biotechnol. 121-124: 334-346.

Vessoni Penna TC, Jozala AF, Novaes LCL, Pessoa .Jr. A, Cholewa O (2005). Production of nisin by Lactococcus lactis in media with skimmed milk. Appl. Biochem. Biotechnol. 121-124: 619-637.

Vessoni Penna TC, Moraes DA (2002) Optimization of nisin production by Lactococcus lactis. Appl. Biochem. Biotechnol. 98-100: 775-789.

Von Sataszewski M, Jagus RJ (2008). Natural antimicrobials: Effect of MicrogardTM and nisin against Listeria innocua in liquid cheese whey. Int. Dairy, 18(3): 255-259.

Yang R, Johnson MC, Ray B (1992). Novel method to extract large amounts of bacteriocins from lactic acid bacteria. Appl. Environ. Microbiol. 58(10): 3355-3359. 